\title{
Storage diseases of onion under variable conditions
}

\author{
MS Mahmud ${ }^{1}$, MS Monjil ${ }^{2 *}$ \\ ${ }^{1}$ Dhamoirhat Degree College, Dhamoirhat, Naogaon, Bangladesh \\ ${ }^{2}$ Department of Plant Pathology, Bangladesh Agricultural University, Mymensingh 2202, Bangladesh
}

\begin{abstract}
Onion (Allium cepa L.) is an important and familiar spice as well as vegetable crop throughout the world. Storage rot due to various diseases caused by bulb rotting fungi is a major constrain for storing onion yearround in Bangladesh. The fungi associated with onion collected from different markets of Mymensingh, Naogaon and Sathkhira districts of Bangladesh were studied aiming to record the incidence of storage diseases as well as storage variability and conditions on disease incidence of onion. Disease incidence was recorded from storage of the retailers in two local varieties of onion,viz.,Taherpuri, Faridpuri and one Indian variety Pusa Red. Initially, infected onion bulbs were found maximum in Faridpuri and minimum amount was found in Pusa Red. Month-wise disease incidence showed that highest number of infected onion bulbs was found in Pusa Red and lowest number of infected bulbs was found in Taherpuri. Similarly highest disease incidence (\%) was recorded in Pusa Red and lowest disease incidence (\%) was recorded in Therpuri. Among the different markets average number of fungal infected bulbs was highest in the samples collected from Dhamoirhat bazaar of Naogaon district and lowest in the samples collected from Natun bazaar of Mymensingh district. Highest infected bulbs were found in onions stored in cold room $\left(6^{\circ} \mathrm{C}\right)$ followed by Free floor and Bamboo basket. Lowest infected bulbs were found in onions stored in dried sands followed by net-bag and jute bag. Thus, the fungal diseases in storage are higher in large sized onion bulbs than indigenous small sized onions and in cold room $\left(6^{\circ} \mathrm{C}\right)$ than net-bag or jute bag.
\end{abstract}

Key words: Onion, Variety, Storage condition, Disease incidence

Progressive Agriculturists. All rights reserve

*Corresponding Author: sumonjil@yahoo.com

\section{Introduction}

Onion (Allium cepa L.) is an important spice as well as vegetable crop in Bangladesh. The major onion growing districts are Faridpur, Comila, Dhaka, Dinajpur, Jessore, Pabna, Rajshahi, Mymensingh and Rangpur (BBS, 2013). Onion is one of the most familiar spice crop throughout the world. It is also used as popular vegetable in Australia, Belgium, India, Japan, UK, USA and many other countries of Asia.

A good number of diseases have been reported in onion and cause production loss in the field and in storage (Munoz et al., 1984; Ahmed and Hossain, 1985; Meah and Khan, 1987). There are many factors behind the losses of onion bulbs in the storage. Under storage condition, onion bulbs naturally loss it's weight due to continuous loss of water. The most serious loss arises from storage rots due to various diseases caused by bulb rotting fungi (Jones and Mann, 1963). About 15 different fungal species and 5 bacterial species are found responsible for the onion diseases in the storage and transit all over the world. The loss due to these diseases is considerable and may go up to $40 \%$ (Aiyer, 1980). In storage various diseases destroy the onions such as Black mould rot (Aspergillus niger), Blue mould rot (Penicillium spp.), Fusarium bulb rot (Fusarium spp.), Basal rot (Fusarium moniliforme), Aspergillus rot (Aspergillus spp.), Dry rot (Macrophomina pha- 
siolina), Soft rot (Erwinia spp.), Smudge (Colletotrichum circinans), Grey neck rot (Botrytis allii), Green mold rot (Penicillium spp.),White rot (Sclerotium cepivorum) and Anthracnose (Colletotrichum chardonianum) (Rangaswami and Mahadevan, 2004). Among these, black mould rot (A. niger) is more severe in storage. A. niger and $A$. flavus infect onion at high temperature and high relative humidity. Whereas Penicillium spp. destroys onion at low temperature. Sometimes Penicillium spp. produces mycotoxin, Penitrem A, which has been previously implicated in tremorgenictoxicosis (Overy et al., 2005). It is reported that the predominant fungal pathogens associated with the storage diseases of onions were Aspergillus sp., Penicillium sp. and Fusarium sp. (Velez et al., 2004, Raju and Nail, 2006). But fewer work have been done on intensity and severity of stored onion diseases in the country. The present research has been undertaken to study the fungi associated with onion bulb collected from different markets of Mymensingh, Naogaon and Sathkhira districts of Bangladesh to record the incidence of storage diseases of onion and to know the storage variability and conditions on disease incidence of onion.

\section{Materials and Methods}

Onion bulbs were collected from three retailer markets of three districts, namely, Natun bazaar of Mymensingh, Dhamoirhat bazaar of Naogaon and Sadar bazaar of Shatkhira of the country. The clinical experiment was carried out in the MS Laboratory, Department of Plant Pathology and in Seed Pathology Centre (SPC), Bangladesh Agriculture University (BAU), Mymensingh. Two local varieties of onion,viz.,Taherpuri, Faridpuri and one Indian variety Pusa Red were selected for this research work. Taherpuri is medium in size with very high pungency; Faridpuri is smaller in size and reddish in color; Pusa Red is large in size with fleshy scales and slight pungent odor.

\section{Collection and storage of onion samples}

Unbiased samples were collected from the stored bag of the retailers. Before storing in the cotton bag each sample of collected onion was sorted out into two categories, viz. healthy looking onions and symptom bearing onions. Onion of all samples were counted, weighted, bagged and labeled. Storage of healthy onions was spread out at room temperature. Five indigenous storage containers were used to store onion, viz., bamboo basket, jute bag, plastic net bag, keep on sand and free floor along with controlled temperature (cold room) at $6^{\circ} \mathrm{C}$.After one week of storage, such a stored sample was spread on a working table and the onion bulbs were sorted out into different categories, such as, i) Healthy looking bulb (with no symptoms/ sign on the bulbs), ii) Black mould rot symptom bearing bulbs, iii) Bulb mould rot symptom bearing bulbs, iv) Fusarium bulb rot symptom bearing bulbs and v) others (having symptom/ sign).The total number of onion in each category were counted and weighted. All these exercise was done on the basis of direct inspection with/ without the aid of a $5 \times$ hand lens.

\section{Percent weight loss and disease incidence}

Percent weight loss was calculated by the following formula:

Weight loss $(\%)=$ (Initial weight of onion bulbsFinal weight of onion bulbs) $\times 100$ / Initial weight of stored onion bulbs

The percentage of disease incidence was calculated using following equation:

Disease incidence $(\%)=$ No. of diseased onion $\times 100 /$ Total no. of onion

\section{Experimental design and statistical analysis}

The laboratory experiment was laid out in a completely Randomized Design (CRD) with three replications. The recorded data on various parameters under the present study were statistically analyzed using MSTAT statistical package program. The level of significance and analysis of variance along with the Least Significance Difference (LSD) were done following Gomez and Gomez (1984).

\section{Result and Discussion}

In the preliminary survey, it was observed that no shopkeepers records any/small systematic information of the actual storage loss and the shop 


\section{Storage diseases of onion}

operators do not know any accurate way of assessing it under prevailing conditions. The losses are mainly due to black mould rot, Fusarium bulb rot, blue mould rot etc. in the markets. Occurrence of the storage diseases of three varieties of onion bulbs viz.,
Taherpuri, Faridpuriad Pusa Red at three different markets was studied. At initial stage of survey, weight of different categories of onion was recorded (Table 1). Highest amount of both apparently healthy bulbs (Kg) and open bulbs were found in Pusa Red

Table 1. Weight of different categories onion at initial stage

\begin{tabular}{|l|c|c|c|c|c|}
\hline \multicolumn{1}{|c|}{ Varieties } & $\begin{array}{c}\text { Name of the } \\
\text { markets }\end{array}$ & $\begin{array}{c}\text { Sample size } \\
(\mathrm{Kg})\end{array}$ & $\begin{array}{c}\text { Apparently Healthy } \\
\text { bulb (Kg) }\end{array}$ & $\begin{array}{c}\text { Open Bulb } \\
(\mathrm{Kg})\end{array}$ & $\begin{array}{c}\text { Infected } \\
\text { bulb (Kg) }\end{array}$ \\
\hline \multirow{2}{*}{ Taherpuri } & $\mathrm{M}$ & 1 & 0.75 & 0.10 & 0.15 \\
\cline { 2 - 6 } & $\mathrm{N}$ & 1 & 0.80 & 0.12 & 0.10 \\
\hline Total & $\mathrm{S}$ & 1 & 0.70 & 0.08 & 0.20 \\
\hline Faridpuri & $\mathrm{M}$ & 3 & 2.25 & 0.30 & 0.45 \\
\cline { 2 - 6 } & $\mathrm{N}$ & 1 & 0.77 & 0.12 & 0.11 \\
\hline Total & $\mathrm{S}$ & 1 & 0.70 & 0.13 & 0.17 \\
\hline Pusa Red & $\mathrm{M}$ & 1 & 0.68 & 0.10 & 0.22 \\
(Indian) & $\mathrm{N}$ & 1 & 2.15 & 0.05 & 0.15 \\
\hline Total & $\mathrm{S}$ & 1 & 0.85 & 0.10 & 0.15 \\
\hline
\end{tabular}

M, Natun bazaar of Mymensingh; N, Dhamoirhat bazaar of Naogaon and S, Sadar bazaar of Shatkhira

variety and lowest amount of both apparently healthy (Kg) bulbs and open bulbs was found in Faridpuri. Infected onion bulbs were found maximum in Faridpuri and minimum amount was found in Pusa Red. Currah and Proctor (1990) surveyed on specific problems on onion production and storage in tropical and sub-tropical regions and indicated that storage losses were serious in 44 out of 72 tropical countries and 19 Asian countries out of 21. Ara et al. (2008) reported that among the five variety tested, artificial inoculation resulted maximum disease in onion bulbs of Indian Pusa Red. Onion bulbs of small sizes with strong skin have good storability (Ko et al., 2002).

Frequency, occurrence of disease onion bulbs collected from three markets of Mymensingh, Naogaon and Shatkhira dristrict in the month of September were measured in respect to variety and different markets of collection (Table 2). Highest average number of fungal infected onion bulbs was found in Pusa Red and lowest average number of fungal infected onion bulbs was found in Taherpuri. Similarly highest disease incidence (\%) was recorded in Pusa Red and lowest disease incidence (\%) was recorded in Taherpuri. Among the different markets average number of fungal infected bulbs was highest in the samples collected from Dhamoirhat bazaar of Naogaon district and lowest in the samples collected from Natun bazaar of Mymensingh district. Similar results were observed in percent disease incidence.Ara et al. (2008) mentioned fungi associated with storage diseases of marketed onions belonging to cultivars Taherpuri, Faridpuri, Kalashnagari, Zitka and Pusa Red. The disease development was significantly different among the varieties. The cultivar Pusa Red was found more susceptible to disease than the bulbs of other cultivars and the cultivar Zitka was found rather resistant (Ara et al., 2008). Visser (1999) published that injury to the bulb incurred before or during storage and this was the key factor in storage disease development causing storage loss. The results of this present study indicate that the fungal diseases in storage are higher in large sized onion bulbs than indigenous small sized onions. Effect of different varieties on onion bulb infection during October/08 to May/09 differed significantly (Table 3). Highest 
infected bulbs were found in onions stored in Faridpuri variety. Lowest infected bulbs were found in Pusa Red. During October/08 to May/09, highest bulb infection was recorded in October/08 and gradually decreased from October to May.

Table 2. Frequency, occurrence of disease onion bulbs collected from three markets of Mymensingh, Naogaon and Shatkhira district in the month of September

\begin{tabular}{|c|c|c|c|c|c|c|}
\hline Varieties & $\begin{array}{l}\text { Name of } \\
\text { the markets }\end{array}$ & $\begin{array}{l}\text { Number of } \\
\text { collected } \\
\text { onions }\end{array}$ & $\begin{array}{l}\text { No. of fungal } \\
\text { infected bulb }\end{array}$ & $\begin{array}{l}\text { Average No. } \\
\text { of fungal } \\
\text { infected bulb }\end{array}$ & $\begin{array}{l}\text { \% disease } \\
\text { incidence }\end{array}$ & $\begin{array}{l}\text { Average \% } \\
\text { disease } \\
\text { incidence }\end{array}$ \\
\hline \multirow[t]{3}{*}{ Taherpuri } & $\mathrm{M}$ & 127 & 13 & \multirow[t]{3}{*}{13} & 10.23 & \multirow[t]{3}{*}{10.45} \\
\hline & $\mathrm{N}$ & 125 & 14 & & 11.20 & \\
\hline & $S$ & 121 & 12 & & 9.92 & \\
\hline \multirow[t]{3}{*}{ Faridpuri } & $\mathrm{M}$ & 132 & 15 & \multirow[t]{3}{*}{16} & 11.36 & \multirow[t]{3}{*}{11.81} \\
\hline & $\mathrm{N}$ & 138 & 17 & & 12.31 & \\
\hline & $S$ & 136 & 16 & & 11.76 & \\
\hline \multirow{3}{*}{$\begin{array}{l}\text { Pusa Red } \\
\text { (Indian) }\end{array}$} & $\mathrm{M}$ & 132 & 18 & \multirow[t]{3}{*}{19} & 13.63 & \multirow[t]{3}{*}{14.44} \\
\hline & $\mathrm{N}$ & 136 & 20 & & 14.70 & \\
\hline & $S$ & 144 & 19 & & 15.00 & \\
\hline
\end{tabular}

M, Natun bazaar of Mymensingh; N, Dhamoirhat bazaar of Naogaon and S, Sadar bazaar of Shatkhira

Table 3. Effect of different varieties on onion bulb infection during October/08 to May/09

\begin{tabular}{|l|l|l|l|l|l|l|l|l|}
\hline \multirow{2}{*}{ Variety } & \multicolumn{6}{l}{ Weight (Mean) of infected bulbs (gm) /Kg } \\
\cline { 2 - 10 } & October & November & December & January & February & March & April & May \\
\hline Taherpuri & 69.67 & 62.28 & 58.00 & 54.67 & 48.50 & 44.50 & 34.33 & 31.50 \\
\hline Faridpuri & 78.67 & 74.67 & 73.17 & 66.33 & 63.17 & 59.83 & 52.67 & 46.17 \\
\hline Pusa red & 61.17 & 58.39 & 53.00 & 47.67 & 41.33 & 37.50 & 34.17 & 32.00 \\
\hline LSD & 0.7303 & 0.8966 & 1.115 & 0.9426 & 1.503 & 1.371 & 1.990 & 1.033 \\
\hline CV (\%) & 1.55 & 2.048 & 2.69 & 2.48 & 4.36 & 4.29 & 7.29 & 4.18 \\
\hline
\end{tabular}

Table 4. Effect of different storage conditions on onion bulb infection during October/08 to May/09

\begin{tabular}{|l|l|l|l|l|l|l|l|l|l|}
\hline \multirow{2}{*}{$\begin{array}{l}\text { Storage } \\
\text { Condition }\end{array}$} & \multicolumn{9}{|c|}{ Weight (Mean) of infected bulbs (gm) /Kg } \\
\cline { 2 - 10 } & October & November & December & January & February & March & April & May \\
\hline Jute bag & 71.00 & 66.00 & 60.00 & 54.00 & 50.00 & 44.67 & 36.33 & 33.67 \\
\hline Net bag & 68.33 & 60.66 & 57.67 & 51.33 & 49.33 & 45.00 & 34.67 & 30.33 \\
\hline Bamboo basket & 70.33 & 65.55 & 62.67 & 60.00 & 52.67 & 49.00 & 37.67 & 33.33 \\
\hline Keep on sand & 65.00 & 60.00 & 54.67 & 47.33 & 41.67 & 37.33 & 30.67 & 26.00 \\
\hline Free floor & 71.66 & 67.77 & 65.67 & 61.67 & 55.67 & 52.33 & 50.00 & 44.67 \\
\hline Refrigerator & 72.66 & 70.66 & 67.67 & 63.00 & 56.67 & 55.33 & 53.00 & 51.33 \\
\hline LSD & 1.033 & 1.268 & 1.577 & 1.333 & 2.126 & 1.938 & 2.815 & 1.460 \\
\hline CV (\%) & 1.55 & 2.04 & 2.69 & 2.48 & 4.36 & 4.29 & 7.29 & 4.18 \\
\hline
\end{tabular}

Among the different months, lowest infection was recorded in May/09. Storage losses were significantly influenced by storage duration, cultivar, storage condition and interaction between storage condition and cultivar (Ko et al. 2002). Effect of different storage conditions on onion bulb infection 
during October/08 to May/09 differed significantly (Table 4). Highest infected bulbs were found in onions stored in cold temperature $\left(6^{\circ} \mathrm{C}\right)$ followed by Free floor and Bamboo basket. Lowest infected bulbs were found in onions stored in dried sands followed by net-bag and jute bag. Consistence month-wise results were obtained. During October/08 to May/09, bulb infection was recorded in October/08 and gradually decreased from October to May. Among the different months, lowest infection was recorded in May/09. Provision of optimum curing and storage condition may enhance the storage performance of onion bulbs (Maw et al., 1997). Storage onion at 0 to $2{ }^{\circ} \mathrm{C}$ and $65 \%$ relative humidity (RH) will minimize storage losses (Handenburg et al., 1986). Srinivasan and Shanmugam (2006) evaluated the efficacy of six types of containers/methods viz., jute gunny bags, polythene lined gunny bag with perforations, bamboo basket, bamboo bins, wooden rake and hanging method in reducing the spoilage in stored onions. They reported that containers used for storage of onion bulbs showed significant influence on the incidence and development of Aspergillus niger rot. Chavan et al. (1992) found hanging method of storage was effective upto 45 days, cage method was effective even upto 90 days in minimising black mould disease of onion.

\section{References}

Ahmed MU, Hossain MM (1985). Final report of the project crop diseases, survey and establishment of herbarium at BARI. Plant Pathology Div. BARI, Gazipur. 170 pp.

Aiyer AKN (1980). Field crops of India with special refer once to Karnataka, (7thed.). Banglore. BAPPCO.

Ara MAM, Khatun ML, Ashrafuzzaman M (2008). Fungi causing rots in onions at storage and market. J. Bangladesh Agril. Univ., 6(2): 245251

BBS (2007). Monthly (October) Statistically Bulletin. Bangladesh Bureau of Statistics. Statistics Division, Ministry of Planning, Govt. of the Peoples Republic of Bangladesh, Dhaka.

Chavan VB, D'Souza TF, Kokate SB, Sawant D M (1992). Efficacy of storage methods for minimizing the bulb rots of onion. Maharashtra J. Hort., 6: 73-75

Currah, L, Proctor FJ (1990). Onions in Tropical Regions, Natural Resources Institute Bulletin No. 35, Natural Resources Institute, Chatham Maritime, Kent, UK, pp 232.

Gomez KA, Gomez AA (1984). Statistical procedures for agricultural research. John Wiley and sons, Inc. London, UK (2nd edtn) 13-175

Hardenburg RE, Watada AE, Wang CY, (1986). The commercial storage of fruits, vegetables, and florist and nursery stocks. U.S. Dept. Agr., Agr. Hdbk. 66

Jones HA, LK Mann (1963). Onions and their allies, botany, cultivations and utilization. Leonard Hill, London.

Ko SS, Chang WN, Wang JF, Cherng SJ, Shanmugasundaram S (2002). Storage variability among short day onion cultivars under high temperature and high relative humidity, and its relationship with disease incidence and bulb characteristics. J. Amer. Soc. Hort. Sci., 127:848-854

Maw BW, Smittle DA, Mullinix BG (1997). Artificially curing sweet onions. Appl. Engi. Agr., 13(4): 517-520

Meah B, Khan AA (1987). Checklist of vegetables and fruit disease in Bangladesh. Dept. of Plant pathology, Bangladesh Agricultural University, Mymensingh. 22pp.

Munoz DCL, Martinez JJP, Perez AP (1984). Onion seed production under tropical conditions. Humbaldt Inst. Fund. Res. Trop. Agric. Acad. Sci., 10 (2): 42-45.

Overy DP, Frisvad JC, Steinmeier U, Thrane U (2005). Clarification of the agents causing blue mold storage rot upon various flower and vegetable bulbs: implications for mycotoxin contamination. Postharvest Biology and Technology., 35 (2): 217-221.

Raju K, Nail MK (2006). Effect of pre-harvest spray of fungicides and botanicals on storage diseases of onion. Indian Phytopath., 59 (2): 133-141 


\section{Storage diseases of onion}

Rangaswami G, Mahadevan A (2004). Diseases of crop plants in India. Prentice-Hall of India private limited.New Delhi-110001.

Srinivasan R, Shanmugam V (2006). Post harvest management of black mould rot of onion. IndianPhytopath., 59 (3) : 333-339

Velez L, Rivera, Rodriguez RP, Cabrera I (2004). Fungi associated with onion (Allium cepa L.) fields in southern Puerto Rico.Journal of Agriculture of the University of Puerto Rico., 88(1/2): 55-72

Visser CLM (1999). Fusarium in onions and varietal differences in infection: evaluation of a biotest. PAV Bulletin Vollegrondsgroenteteelt. 4-7. 